\title{
Yield and quality attributes with seasonal variation in Napier Bajra hybrid (Pennisetum purpureum $\times$ Pennisetum glaucum) under different nitrogen environments
}

\author{
Rupinder Kaur ${ }^{1}$, Meenakshi Goyal ${ }^{2}$ and U. S. Tiwana ${ }^{2}$ \\ ${ }^{1}$ Department of Biochemistry, Punjab Agricultural University, Ludhiana-141004 (Punjab), INDIA \\ ${ }^{2}$ Department of Plant Breeding \& Genetics, Punjab Agricultural University, Ludhiana-141004 (Punjab), INDIA \\ Corresponding author email: meenakshigoyal@pau.edu
}

Received: April 7, 2016; Revised received: February 20, 2017; Accepted: July 5, 2017

\begin{abstract}
Field experiment was conducted during kharif season of 2013 in randomized block design using three nitrogen doses $(50,75$ and $100 \mathrm{kgN} / \mathrm{ha}$ ) with three replications for Napier Bajra hybrid. Three nitrogen fertilizers, potassium nitrate $\left(\mathrm{KNO}_{3}\right)$, urea $\left[\mathrm{CO}\left(\mathrm{NH}_{2}\right)_{2}\right]$ and ammonium sulphate $\left[\left(\mathrm{NH}_{4}\right)_{2} \mathrm{SO}_{4}\right]$ were used in divided doses. The crop was harvested four times in different seasons. Growth attributes viz. plant height $(72.6 \mathrm{~cm})$, number of tillers per plant (20.1) and leaf length (91.2) found highest at $100 \mathrm{kgN} / \mathrm{ha}$ doses and maximum values were recorded in monsoon season. Green fodder yield (321.0 q/ha) and dry fodder yield (79.6 q/ha) were recorded highest with $\mathrm{KNO}_{3}$ fertilization and found maximum in monsoon season. Among all the harvest seasons, crude protein yield (19.1 q/ha) was observed maximum in summer season. Quality attributes viz. ether extract (2.6\%), ash content (12.9\%) and in vitro dry matter digestibility $(62.6 \%)$ were observed highest in summer season. Crude fibre, neutral detergent fibre and acid detergent fibre decreased with increased level of nitrogen doses and observed maximum in monsoon season.
\end{abstract}

Keywords: Growth attributes, Harvest seasons, Napier Bajra hybrid, Nitrogen fertilization, Yield

\section{INTRODUCTION}

Napier Bajra Hybrid, cv, PBN-233 (Pennisetum purpureum $\times$ Pennisetum glaucum) is a popular fodder for rearing the livestock because of its higher biomass yield and its suitability for feeding the dairy cattle, sheep and goats. It is an important fast growing multicut fodder crop and provides fodder from April to November. Bajra $\times$ Napier hybrid is a heavy feeder crop and due to multi-cut ability its nutritional requirement is also very high as it gives better response to evaluated level of fertilizers (Pathan et al., 2012). Hence it was felt necessary to study fertilizer levels and seasonal variation in present investigation to maximize the quantity and quality of green fodder. Nitrogen $(\mathrm{N})$ is a fundamental regulator of plant growth and its supply strongly influence plant growth. Plant N status depends on soil nitrogen availability as well as plant uptake and assimilation capacity. In general, the availability of the nutrients influence the quality of various crops. The increase in nitrogen fertilization improved considerably nitrogen uptake and would contributed to large photosynthetic activity and synthesis of higher protein content (Rostamza et al., 2011). Plant quality was sensitive to the growing conditions, especially nitrogen level (Wang et al., 2007). Seasonal variations affected the availability of the nutrients from the soil to forage species leucaena/gliricidia-Guinea grass mixtures (Ezenwa et al., 1995). The nutritional values of forage species were low in the dry seasons compared to the wet seasons (Buxton, 1996). This was as a result of the dependence of grass nutrient contents on the amount of moisture found in the soil in which the forage plants were grown (McDowell et al., 1983). High proximate composition of the forage species in the rainy season might be due to high concentration of minerals. These minerals might act as precursors to the proximate formation in the rainy season and acted as essential cofactors of metabolic reactions which were responsible to activate enzymes (George et al., 2005). Harvest time also influenced green forage and dry fodder yield and trend of both parameters were exactly similar (Ayub et al., 2009). Increased supply of nitrogen and other nutrients increased the protein content whereas decreased the NDF and ADF content (Patel et al., 2007). Fodders with lower ADF and higher protein content were easily digestible by ruminants and those with higher ADF and lower protein content could not be considered suitable to feed. Thus, the system of characterization of protein was to be valuable in estimating dietary protein and nitrogenous nutrients (Sharma and Chandra, 2004). In a study of fodder maize, nitrogen application resulted in greater values of plant height, leaf area, number of leaves and stem diameter, fresh and dry 
forage yield (Koul, 1997). Keeping this in view, the present investigation was carried out to evaluate the effect of nitrogen fertilization in different forms on yield and quality attributes of Napier Bajra hybrid in different harvest seasons.

\section{MATERIALS AND METHODS}

The present investigation was carried out on Napier Bajra Hybrid (PBN 233) (Pennisetum purpureum $\times$ Pennisetum glaucum) raised in the experimental field of Forage Research Farm, Department of Plant Breeding and Genetics, Punjab Agricultural University, Ludhiana. Stem cuttings with two or three nodes were used for planting. A small portion of shoot-slip was allowed to remain exposed and the rest of the slip was buried in the soil. The crop was planted at $90 \times 40 \mathrm{~cm}$ apart in lines under good conditions of soil moisture in April using random block design (RBD) with three replications. The fertilizers were applied in two intervals at the time of irrigation and after the 10 days of sowing/previous cut or harvest. Plant tops were harvested ( $15 \mathrm{~cm}$ above the soil surface) four times ( $1^{\text {st }}$ to $4^{\text {th }}$ harvest i.e, June to October). First cut was taken after 60 days of sowing (DOS) in June and subsequent cuts were taken after an interval of 35-40 days. Yield and growth attributes were measured at the time of harvesting in different seasons i.e., Summer, Monsoon, Autumn and Pre-winter. Fresh plant leaf samples were collected after every harvest, sun dried and then completely dried in hot air oven till a constant weight was obtained. This dried plant material was ground using Willy grinder to a uniform mesh size. The standard methods were used for the estimation of neutral detergent fibre and acid detergent fibre (Goering and Van Soest, 1970), in vitro dry matter digestibility (Tilley and Terry, 1963), ether extract, ash, crude fibre and crude protein (AOAC, 1970). Data was statistically analyzed using analysis of variance (ANOVA). Further mean separation of treatment effects was accomplished by using Fisher's protected least significant difference test. All data analysis was carried out using SAS software.

\section{RESULTS AND DISCUSSION}

Growth attributes: In the present study, Napier Bajra plant height increased significantly $(\mathrm{p}<0.001)$ with nitrogen fertilization rate (Table 1$)$. Increasing trend with $\mathrm{N}$ fertilization could be ascribed to the role of nitrogen in stimulating cell division, consequently internodes elongation and development in Pearl millet (Ali, 2010). Highest plant height $(72.6 \mathrm{~cm})$ was recorded at $100 \mathrm{~kg} \mathrm{~N} /$ ha doses while lowest $(64.9 \mathrm{~cm})$ at 50 $\mathrm{kg} \mathrm{N} /$ ha doses. Increase in plant height with nitrogen fertilization of $(0-180 \mathrm{kgN} / \mathrm{ha}),(0-30 \mathrm{kgN} / \mathrm{ha})$ and $(0-$ $100 \mathrm{kgUrea} / \mathrm{ha})$ also observed by other workers in pearl millet (Ayub et al., 2009), cowpea (Hasan et al., 2010) and Chickpea (Namvar et al., 2013) respectively. Among $\mathrm{N}$ sources, maximum plant height $(\mathrm{cm})$ was observed with ammonium sulphate (69.9) application as compared to urea (68.4) and $\mathrm{KNO}_{3}(68.0)$ treated plants $(\mathrm{p}>0.05)$. Among the different harvest seasons, overall harvest mean showed maximum rise in plant height $(\mathrm{cm})$ in the monsoon (100.5) season whereas the minimum plant height was recorded in pre-winter (49.2) season with nitrogen fertilization $(p<0.001)$.

In the current study, increase in nitrogen fertilization rates significantly $(\mathrm{p}<0.001)$ resulted increase in the number of tillers/plant (Table 1). Overall effect of $\mathrm{N}$ fertilization for number of tillers/plant was ranged from 17.9 - 20.1. Similar result was obtained by increasing the nitrogen doses within the range of $0-160$ $\mathrm{kgN} / \mathrm{ha}$ in oat fodder (Hasan and Shah, 2000). Among the $\mathrm{N}$ sources, number of tillers/plant were maximum with ammonium sulphate (19.4) fertilization followed by urea (19.1) and potassium nitrate (18.6) fertilization ( $>0.05)$. Number of tillers/plant was maximum in monsoon (24.4) season and minimum in pre-winter (12.6) season $(\mathrm{p}<0.001)$. Similarly, Batista et al. (2014) reported increased number of tillers in the second growth of the Ruzi grass with nitrogen fertilization rates of $0-45 \mathrm{mg} / \mathrm{dm}$.

In the present study, leaf length was increased with nitrogen application $(\mathrm{p}<0.001)$ (Table 1$)$. Leaf length was ranged from $85.8-91.2 \mathrm{~cm}$ with increasing $\mathrm{N}$ fertilization rate. It varied significantly $(p<0.01)$ among different $\mathrm{N}$ forms. Regardless the seasons, mean values were maximum in $\mathrm{KNO}_{3}(90.3 \mathrm{~cm})$ treated plants but minimum in $\left(\mathrm{NH}_{4}\right)_{2} \mathrm{SO}_{4}(86.7 \mathrm{~cm})$ treated plants. Among the harvest seasons, leaf length also significantly $(p<0.001)$ different from each other. Harvest mean showed highest leaf length in monsoon $(102.3 \mathrm{~cm})$ season and lowest in summer $(83.4 \mathrm{~cm})$ season. Harvest season interacted significantly $(\mathrm{p}<0.001)$ with $\mathrm{N}$ sources.

Yield: Green fodder yield (GFY, q/ha) increased with nitrogen fertilization $(\mathrm{p}<0.001)$ and highest yield was observed with $100 \mathrm{~kg} \mathrm{~N} /$ ha dose (Table 2). Similarly higher green fodder yield with increasing nitrogen fertilization rates was recorded in hybrid Napier genotypes (Tiwana et al., 2004, Vinay Raj and Palled, 2014). The increase in green fodder yield of forage under nitrogen application could be attributed to the positive effect of nitrogen on all the growth parameters investigated in this study as forage yield is a function of growth parameters. Among different N sources, GFY was recorded highest with $\mathrm{KNO}_{3}$ fertilization $(321.0 \mathrm{q} / \mathrm{ha})$ followed by $\mathrm{CO}\left(\mathrm{NH}_{2}\right)_{2}(315.2 \mathrm{q} / \mathrm{ha})$ and $\left(\mathrm{NH}_{4}\right)_{2} \mathrm{SO}_{4}$ fertilization $(303.8 \mathrm{q} / \mathrm{ha})(\mathrm{p}<0.001)$. The GFY also varied significantly $(\mathrm{p}<0.001)$ with harvest season. The effect of $\mathrm{N}$ application is not always the same and depends on agro-climatic conditions. The highest yield was achieved in monsoon (518.1 q/ha) season and lowest in pre-winter (199.1 q/ha) season. $\mathrm{N}$ doses and $\mathrm{N}$ forms had significant effect on average GFY yield $(\mathrm{p}<0.05)$ in four harvest seasons. 
Rupinder Kaur et al. / J. Appl. \& Nat. Sci. 9 (3): 1350 - 1357 (2017)
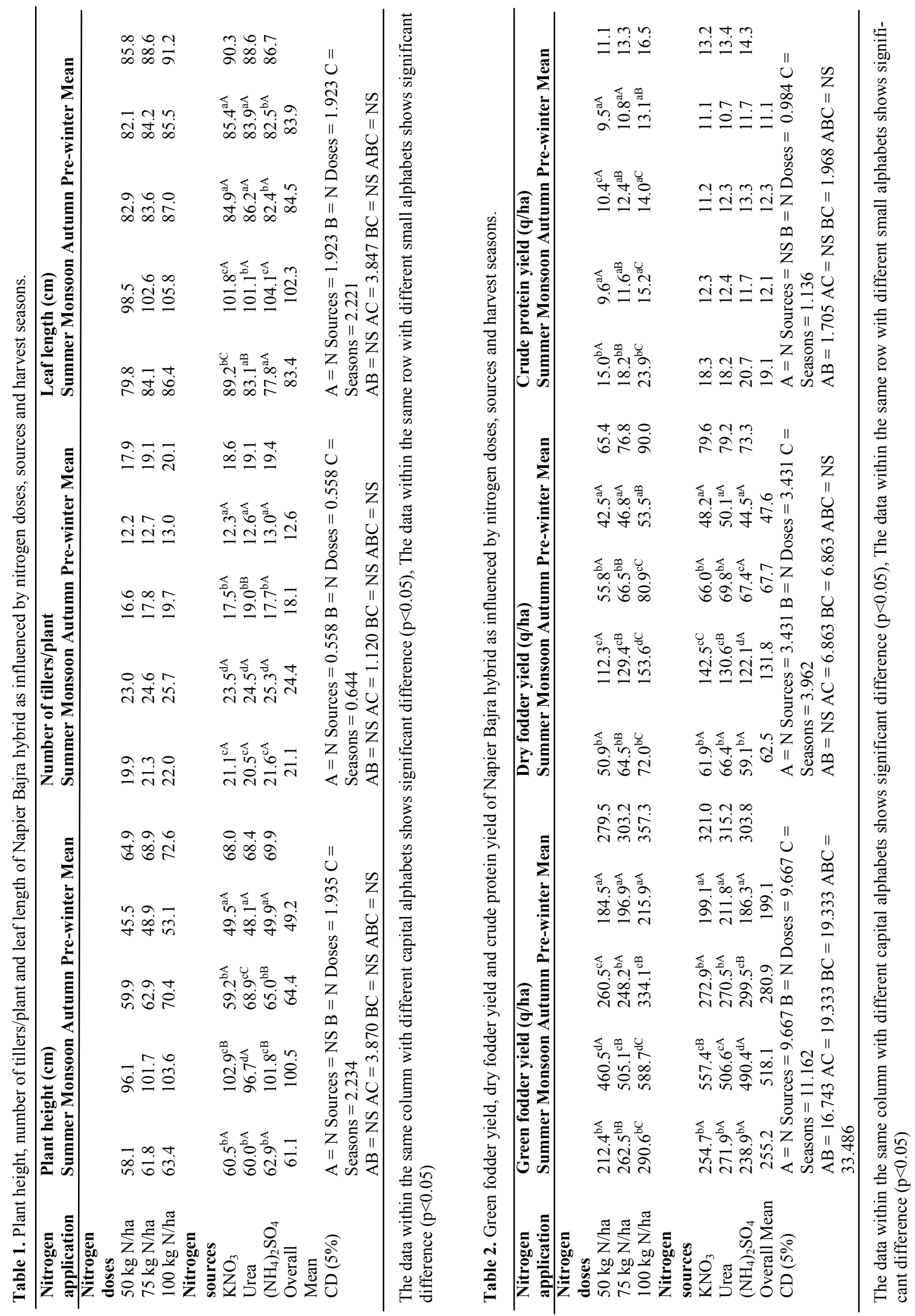
Rupinder Kaur et al. / J. Appl. \& Nat. Sci. 9 (3): 1350 - 1357 (2017)
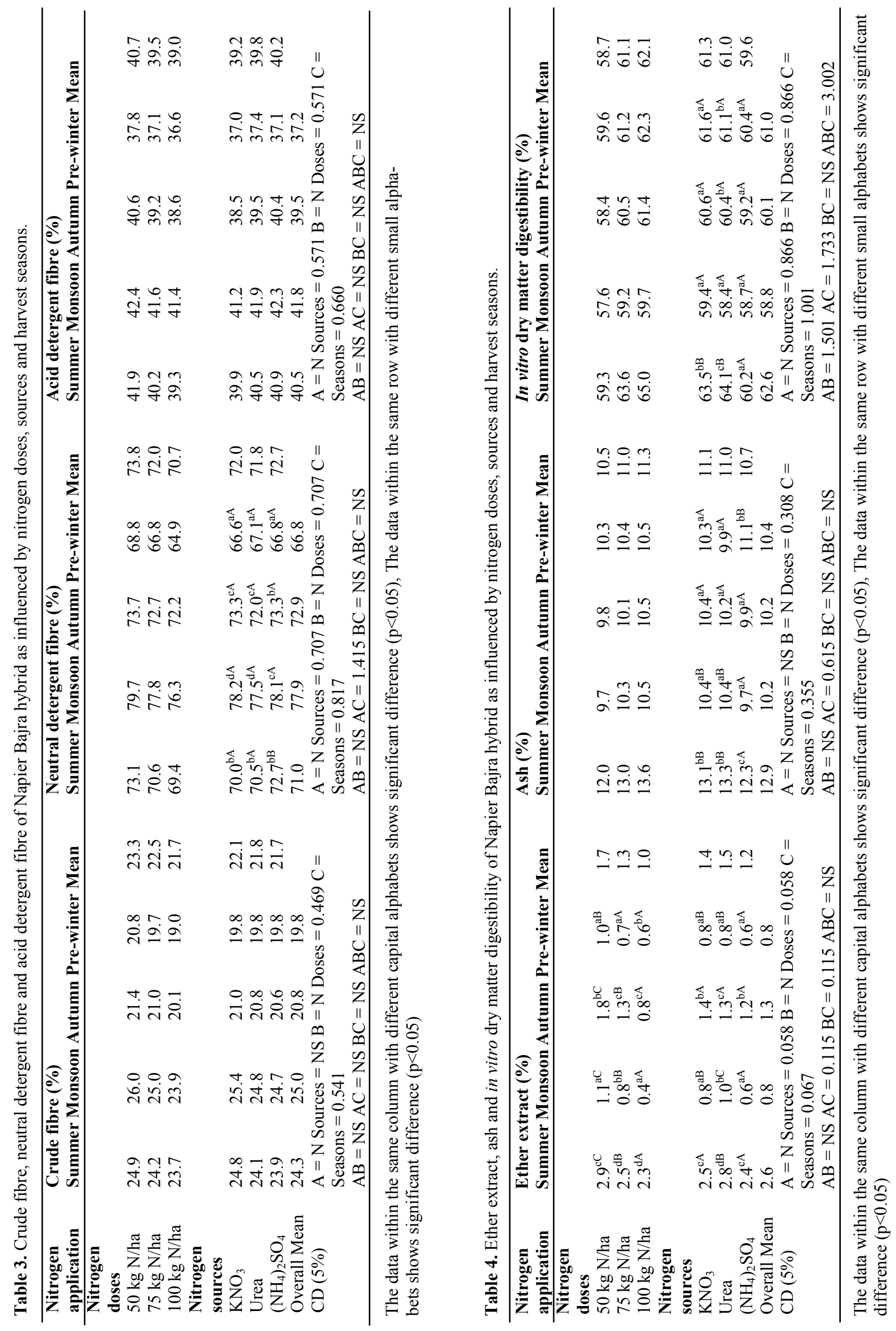
Table 5. Correlation coefficients betweengrowth attributes, yield and quality attributes of Napier Bajra hybrid as influenced by nitrogen doses and sources.

\begin{tabular}{|c|c|c|c|c|c|c|c|c|c|c|c|}
\hline & $\begin{array}{c}\text { Plant } \\
\text { height }\end{array}$ & $\begin{array}{l}\text { Num- } \\
\text { ber of } \\
\text { tiller/ } \\
\text { plant }\end{array}$ & $\begin{array}{c}\text { Leaf } \\
\text { length }\end{array}$ & GFY & $\overline{D F Y}$ & CPY & $\mathrm{CF}$ & NDF & ADF & EE & Ash \\
\hline $\begin{array}{l}\text { Number of } \\
\text { tillers/plant }\end{array}$ & $.999^{*}$ & & & & & & & & & & \\
\hline Leaf length & $1.000^{*}$ & $.999 *$ & & & & & & & & & \\
\hline GFY & .974 & .963 & .971 & & & & & & & & \\
\hline DFY & $.999 *$ & .996 & $.998 *$ & .984 & & & & & & & \\
\hline CPY & .994 & .987 & .992 & .993 & $.998 *$ & & & & & & \\
\hline $\mathrm{CF}$ & $-1.000^{*}$ & $-.999 *$ & $-1.000 *$ & -.975 & $-.999 *$ & -.994 & & & & & \\
\hline NDF & -.996 & $-.999 *$ & $-.998 *$ & -.951 & -.991 & -.980 & .996 & & & & \\
\hline $\mathrm{ADF}$ & -.974 & -.984 & -.977 & -.898 & -.962 & -.943 & .973 & .990 & & & \\
\hline $\mathrm{EE}$ & $-.997 *$ & $-1.000^{*}$ & $-.998 *$ & -.954 & -.992 & -.982 & $.997 *$ & $1.000^{*}$ & .988 & & \\
\hline Ash & .991 & .996 & .993 & .934 & .983 & .969 & -.990 & $-.999 *$ & -.996 & $-.998 *$ & \\
\hline IVDMD & .975 & .984 & .978 & .898 & .962 & .943 & -.973 & -.991 & $-1.000^{*}$ & -.989 & .996 \\
\hline
\end{tabular}

$*=$ significant at $5 \%$ level of significance

Increase in dry fodder yield (DFY, q/ha) resulted from increase in nitrogen fertilization rates $(\mathrm{p}<0.001)$ (Table 2). Previous studies also reported increased dry fodder yield with increasing nitrogen rate of $0-180 \mathrm{kgN} / \mathrm{ha}$ and $150-225 \mathrm{kgN} / \mathrm{ha}$ in slender meadow foxtail, cheat grass, rough blue grass, perennial ryegrass (Aydin and Uzun, 2005) and Bajra napier hybrid respectively (Pathan et al., 2012). In the present study, DFY ranged from $60.7-94.8 \mathrm{q} / \mathrm{ha}$ with increase in $\mathrm{N}$ application rate. Among nitrogen sources, $\mathrm{KNO}_{3}(79.6 \mathrm{q} / \mathrm{ha})$ treated plants showed higher DFY than $\mathrm{CO}\left(\mathrm{NH}_{2}\right)_{2}(79.2 \mathrm{q} /$ ha) and $\left(\mathrm{NH}_{4}\right)_{2} \mathrm{SO}_{4}(73.3 \mathrm{q} / \mathrm{ha})$ treated plants. Among harvest seasons, DFY was recorded highest in monsoon $(131.8 \mathrm{q} / \mathrm{ha})$ season while the least was observed in pre-winter $(47.6 \mathrm{q} / \mathrm{ha})$ season. Harvest seasons showed significant interaction with $\mathrm{N}$ doses $(\mathrm{p}<0.001)$ and $\mathrm{N}$ sources $(\mathrm{p}<0.001)$.

Crude protein yield (CPY) increased significantly $(p<0.001)$ with nitrogen fertilization rates (Table 2). This might be due to more rapid conversion of carbohydrates to proteins under higher nitrogen supply. Highest CPY was recorded with higher fertility level of nitrogen. Inadequate sup-ply of available $\mathrm{N}$ frequently resulted in depressed protein levels in plant and generally, protein content increased with nitrogen uptake (Mikkelsen and Hartz, 2008). Among N sources, there was marginal increase of $\mathrm{CP}$ yield in $\left(\mathrm{NH}_{4}\right)_{2} \mathrm{SO}_{4}$ treated plants $(\mathrm{p}>0.05)$. Ammonium form of nitrogen fertilization gave maximum CPY (14.3 q/ ha) followed by amide $(13.4 \mathrm{q} / \mathrm{ha})$ and nitrate $(13.2 \mathrm{q} /$ ha) form. In fodder maize, lower CP content was observed in urea treated plants than ammonium sulphate treated plants (Hassan Amin, 2011). Similarly CP content was found higher in ammonium treated lucerne plants as compared to nitrate treated plants (Vasileva and Ilieva, 2011). With nitrogen fertilization, overall harvest mean showed maximum CPY in summer (19.1 $\mathrm{q} / \mathrm{ha}$ ) season which was decreased in monsoon (12.1 q/
Table 6. Correlation coefficients between growth attributes and yield of Napier Bajra hybrid as influenced by harvest seasons.

\begin{tabular}{lllll}
\hline & $\begin{array}{l}\text { Plant } \\
\text { height }\end{array}$ & $\begin{array}{l}\text { Number of } \\
\text { tillers/plant }\end{array}$ & $\begin{array}{l}\text { Leaf } \\
\text { length }\end{array}$ & GFY \\
\hline $\begin{array}{l}\text { Number of } \\
\text { tillers/plant }\end{array}$ & .841 & & & \\
Leaf length & $1.000^{*}$ & .854 & & \\
GFY & $1.000^{*}$ & .834 & $.999^{*}$ & \\
DFY & $1.000^{*}$ & .845 & $1.000^{*}$ & $1.000^{*}$ \\
\hline
\end{tabular}

$*=$ significant at $5 \%$ level of significance

ha), slightly increased in autumn (12.3 q/ha) and lowest CPY was observed in pre-winter $(11.1 \mathrm{q} / \mathrm{ha})$ season $(\mathrm{p}<0.001)$. The maximum CP yield in summer season might be due to the peak metabolic activities in summer season. Similarly in Bermuda grass forage, crude protein was increased with nitrogen application in both spring and summer harvests (May et al., 2007).

Quality attributes: Higher doses of nitrogen fertilization significantly $(\mathrm{p}<0.001)$ resulted in decrease in the CF content (Table 3). Similar results were also reported by increasing the nitrogen doses of $40-160 \mathrm{mg}$ ammonium nitrate/kg soil and $0-225$ urea/ha in lucerne (Ilieva and Vasileva, 2010) and pearl millet respectively (Rostamza et al., 2011). In the present study, CF content was ranged from $21.7-23.3 \%$ with nitrogen fertilization. However, Bandeswaran et al. (2013) found that crude fibre content was not influenced by the level of inorganic nitrogen application in Napier Bajra hybrid. Nitrogen sources did not interact significantly $(\mathrm{p}<0.05)$ with $\mathrm{N}$ doses. $\mathrm{CF}$ also showed variations with seasonal fluctuations $(\mathrm{p}<0.001)$. CF content was found maximum in monsoon $(25.0 \%)$ season followed by summer $(24.3 \%)$, autumn $(20.8 \%)$ and prewinter $(19.8 \%)$ seasons. When forages harvested several times during the growing seasons, the changes in environment conditions affect distribution of $\mathrm{CF}$ be- 
tween harvests (Cherney and Volenec, 1992).

Neutral detergent fibre (NDF) represents total fibre fraction (cellulose, hemicellulose, lignin and silica) that make up cell walls of the forage tissue. Forages with high concentrations of fibre generally support less milk production as these contain less available energy and are consumed in lesser amounts by livestock. NDF content showed reverse trend to crude protein yield and decreased significantly $(\mathrm{p}<0.001)$ with nitrogen fertilization (Table 3). Similar types of findings were also observed in urea treated hybrid napier plants (Sharma et al., 2012). Among each N source, highest NDF content was observed in $\left(\mathrm{NH}_{4}\right)_{2} \mathrm{SO}_{4}(72.7 \%)$ treated plants as compared to $\mathrm{KNO}_{3}(72.0 \%)$ and $\mathrm{CO}\left(\mathrm{NH}_{2}\right)_{2}(71.8 \%)$ treated plants $(\mathrm{p}<0.05)$. Irrespective of $\mathrm{N}$ sources, harvest mean was found variable in each season $(p<0.001)$. On average among each harvest season, NDF content was obtained highest in monsoon (77.9\%) season while lowest in pre-winter $(66.8 \%)$ season.

Acid detergent fibre (ADF) represents cellulose, lignin and silica. It was a major indicator of digestibility and its higher level negatively affect feed quality (Han et al., 2003). Likewise NDF, ADF also decreased significantly $(\mathrm{p}<0.001)$ with nitrogen fertilization (Table 3$)$. Kering et al. (2011) observed that $\mathrm{N}$ fertilization consistently decreased ADF content in bermuda grass forage. Similarly, the decreased ADF content with N application in different cuts of hybrid Napier was also recorded by Sharma et al. (2012). In many studies, ADF values did not change significantly under the influence of $\mathrm{N}$ fertilization (Kopp et al., 2003, Knežević et al., 2007, Salis and Vargiu, 2008). Among the nitrogen sources, maximum ADF content was recorded in $\left(\mathrm{NH}_{4}\right)_{2} \mathrm{SO}_{4}(40.2 \%)$ treated plants followed by $\mathrm{CO}\left(\mathrm{NH}_{2}\right)_{2}(39.8 \%)$ and $\mathrm{KNO}_{3}(39.2 \%)$ treated plants $(\mathrm{p}<0.01)$. ADF content was found maximum in monsoon $(41.8 \%)$ season and lowest in pre-winter $(37.2 \%)$ season.

Nitrogen applied to the plants in any form resulted in decrease in EE level $(p<0.001)$ and the values ranged from 1.0 - $1.7 \%$ with $\mathrm{N}$ application (Table 4). However, there were studies showing that the content of ether extracts increased with addition of $\mathrm{N}$ (Vučković et al., 2005). The content of EE varied with different $N$ sources $(p<0.001)$. Irrespective of harvest seasons, urea treated plants exhibited maximum (1.5\%) EE content followed by potassium nitrate $(1.4 \%)$ and ammonium sulphate $(1.2 \%)$ treated Napier Bajra plants. In different harvest seasons, overall harvest mean showed maximum EE content in summer $(2.6 \%)$ season and minimum in pre-winter $(0.8 \%)$ season. Onyeonagu and Eze (2013) also observed higher ether extract in Pennisetum purpureum during rainy season as compared to dry season which was in favour of our present results because rainfall was maximum in summer season during experimental period.

Ash content was maximum during the early stages of growth. It increased significantly $(\mathrm{p}<0.001)$ with nitrogen fertilization (Table 4). Studies indicated that the rates of nitrogen inputs were important to maximize the level of nutrients in plants (Odunze et al., 2004, Russo, 2006). Similar results regarding the increased percentage of ash content with nitrogen application was obtained in pearl millet (Ayub et al., 2009). Irrespective of seasons, ash content was ranged from 10.5 $-11.3 \%$ with nitrogen fertilization. Highest ash content was recorded in $\mathrm{KNO}_{3}(11.1 \%)$ treated plants followed by $\mathrm{CO}\left(\mathrm{NH}_{2}\right)_{2}(11.0 \%)$ and $\left(\mathrm{NH}_{4}\right)_{2} \mathrm{SO}_{4}$ treated plants. In different harvest seasons, harvest mean showed maximum ash content in summer (12.9\%) season whereas minimum in autumn (10.2\%) and monsoon (10.2\%) seasons $(p<0.001)$. Higher mineral content was also observed in baby corn at early stages than in later stages (Thavaprakaash et al., 2008). Previous study on different forage grasses showed significantly $(p<0.05)$ higher mineral content percent in rainy season than in dry season which supported our present results (Onyeonagu and Eze, 2013).

In vitro dry matter digestibility (IVDMD) increased significantly $(\mathrm{p}<0.001)$ with nitrogen application (Table 4). The digestibility was increased from 58.7 $62.1 \%$ with $\mathrm{N}$ application. An increasing trend of IVDMD with $\mathrm{N}$ application in Napier Bajra hybrid was also observed by Pathan et al. (2012). Among N sources, highest IVDMD was observed in $\mathrm{KNO}_{3}$ $(61.3 \%)$ treated plants followed by $\mathrm{CO}\left(\mathrm{NH}_{2}\right)_{2}(61.0 \%)$ and ammonium sulphate $(59.6 \%)$ treated plants $(\mathrm{p}<0.001)$. N sources interacted significantly $(\mathrm{p}<0.05)$ with $\mathrm{N}$ doses. Among harvest seasons, overall harvest mean observed highest values in summer $(62.6 \%)$ season and lowest in monsoon $(58.8 \%)$ season $(\mathrm{p}<0.001)$. Vough and Marten (1971) reported decreased IVDMD with reduced leaf to stem ratio in alfalfa forage. In the present study, the trend of IVDMD in different seasons was proportional to crude protein yield.

Correlation studies: In relation to different nitrogen fertilization levels and sources, plant height showed positive correlation with number of tillers/plant ( $r$ $\left.=.999^{*}\right)$, leaf length $\left(\mathrm{r}=1.000^{*}\right)$ and DFY $\left(\mathrm{r}=.999^{*}\right)$ whereas negative correlation with $\mathrm{CF}\left(\mathrm{r}=-1.000^{*}\right)$ and $\mathrm{EE}(\mathrm{r}=-.997 *)$ at $5 \%$ level of significance (Table 5). DFY revealed positive correlation with CPY ( $\mathrm{r}$ $\left.=.998^{*}\right)$ whereas negative correlation with $\mathrm{CF}(\mathrm{r}=$ $\left..999^{*}\right)$. CF was positively correlated to $\mathrm{EE}\left(\mathrm{r}=.997^{*}\right)$. A negative correlation was found between ADF and IVDMD $\left(\mathrm{r}=-1.000^{*}\right)$. In relation to harvest seasons, no correlation was observed within quality attributes whereas a significant correlation $(\mathrm{p}<0.05)$ was found between growth attributes and yield of Napier Bajra hybrid (Table 6).

\section{Conclusion}

To sum up the finding we can conclude that both yield and quality improve with increasing nitrogen fertiliza- 
tion doses. Among fertilizers, potassium nitrate and ammonium sulphate gave better results in terms of GFY (321.0 q/ha) and CPY (14.3 q/ha) respectively. Seasons have great impact on quality of crop. Therefore, CPY (19.1 q/ha), ash (12.9\%) and IVDMD $(62.6 \%)$ were highest during early stage of growth whereas CF (25.0\%), NDF (77.9\%), ADF (41.8\%), plant height $(100.5 \mathrm{~cm})$, number of tillers/plant $(24.4)$, leaf length $(102.3 \mathrm{~cm})$, GFY (518.1 q/ha) and DFY (131.8 q/ha) were highest in monsoon season.

\section{REFERENCES}

Ali, E. A. (2010). Grain yield and Nitrogen Use Efficiency of Pearl Millet as Affected by Plant Density, Nitrogen Rate and Splitting in Sandy Soil. Am-Eur. J. Agric. and Environ. Sci. 7(3): 327-335.

AOAC. (1970). Official Methods of Analysis. Association of Official Analytical Chemists. $11^{\text {th }}$ edition. Washington, D.C.

Aydin, I. and Uzun, F. (2005). Nitrogen and phosphorus fertilization of rangelands affects yield, forage quality and the botanical composition. Eur. J. Agron. 23: 8-14.

Ayub, M., Nadeem, M. A., Tahir, M., Ibrahim, M. and Aslam, M. N. (2009). Effect of nitrogen application and harvesting intervals on forage yield and quality of pearl millet (Pennisetum americanum L.). Pak. J. Life. Soc. Sci. 7(2): 185-189.

Bandeswaran, C., Radhakrishnan, L. and Murugan, M. (2013). Influence of various types of organic manures and different levels of nitrogen fertilization on the biomass yield and nutrient content of Napier-bajra hybrid grass. Inter. J. Vet. Sci. 2(3): 93-95.

Batista, K., Giacomini, A. A., Gerdes, L., Mattos, W. T., Colloza, M. T. and Otsuk, I. P. (2014). Influence of Nitrogen on the production characteristics of ruzi grass. African J. Agric. Res. 9(5): 533-538.

Buxton, D. R. (1996). Quality related characteristics of forages as influenced by plant environment and agronomic factors. Anim. Feed Sci. Technol. 59: 37-49.

Cherney, J. H. and Volenec, J. J. (1992). Forage evolution as influenced by environmental replication: A review. Crop Sci. 32: 841.

Ezenwa, I. V., Reynolds, Z., Aken'Ova, M. E., Attakpahs, I. A. N. and Cobbina, J. (1995). Cutting Management of Alley Cropped leucaena gliricidia - Guinea Grass Mixtures for forage production in southwestern Nigeria: Livestock Research for Rural Development. Agrofor. Syst. 44: 13-19.

George, M. F., Lin, C. H., Lerch, R. N. and Garrett, H. E. (2005). Incorporating forage grasses in riparian buffers for bioremediation of atrazine isoxaflutole and nitrate in Missouri. Agrofor. Syst. 63: 87-95.

Goering, H. K. and Van Soest, P. J. (1970). Forage Fibre Analysis, Apparatus reagents, procedures and some application. Agriculture Hand Book No. 379, USDA Washington, D.C.

Han, F., Ullrich, S. E., Romagosa, I., Clancy, J. A., Froseth, J. A. and Wesenberg, D. M. (2003). Quantitative genetic analysis of acid detergent fibre content in barley grain. J. Cereal Sci. 38: 167-172.

Hasan, B. and Shah, W. A. (2000). Biomass grain production and quality of oat (Avena sativa) under different cutting regimes and nitrogen levels. Cereal Res. Commun. 28(1 -2): 203-210.

Hasan, M. R., Akbar, M. A., Khandaker, Z. H. and Rahman, M. M. (2010). Effect of nitrogen fertilizer on yield contributing character, biomass yield and nutritive value of cowpea forage. Bang. J. Anim. Sci. 39(1\&2): 83-88.

Hassan Amin, M. El-M. (2011). Effect of different nitrogen sources on growth, yield and quality of fodder maize (Zea mays L.). J. Saudi Soc. Agric. Sci. 10: 17-23.

Ilieva, A. and Vasileva, V. (2010). Variation in chemical composition of lucerne varieties in conditions of water deficiency stress. J. Mountain Agric. on the Balkans 13 (5): 1106-1117.

Kering, M. K., Guretzky, J., Funderburg, E. and Mosali, J. (2011). Effect of nitrogen fertilizer rate and harvest season on forage yield, quality, and macronutrient concentrations in Midland bermuda grass. Commun. Soil Sci. Plant Anal. 42: 1958-1971.

Knežević, M., Leto, J., Perčulija, G., Bošnjak, K. and Vranić, M. (2007). Effect of liquid manure application on yield quality and botanical composition of grassland. VI. Alps-Adria Scientific Workshop, Obervellach, Australia. pp 637-640.

Kopp, J. C., Mccaughey, W. P. and Wittenberg, K. M. (2003). Yield, quality and cost effectiveness of using fertilizer and/or alfalfa to improve meadow bromegrass pastures. Can. J. Anim. Sci. 83: 291-298.

Koul, G. G. (1997). Effect of sowing methods, nitrogen levels and seed rates on yield and quality of fodder maize (Zea mays L.). M.Sc. thesis, Faculty of Agric, University of Khartoum.

May, W. E., Klein, L., Lafond, G. P., McConnell, J. T. and Phelps, S. M. (2007). The suitability of cool and warm season annual cereal species for winter grazing in Saskatchewan. Can. J. Plant Sci. 87: 739-752.

McDowell, L. R., Conrad, G. H., Ellis, G. L. and Loosli, J. K. (1983). Minerals for Grazing Ruminants in Tropical Regions. University of Florida Gainesville, Florida 13: 121-128.

Mikkelsen, R. and Hartz, T. K. (2008). Nitrogen Sources for Organic Crop Production. Better Crops. 92(4): 16-19.

Namvar, A., Sharifi, R. S., Khandan, T. and Moghadam, M. J. (2013). Seed inoculation and inorganic nitrogen fertilization effects on some physiological and agronomical traits of chickpea (Cicer arietinum L.) in Irrigated Condition. J. Central Eur. Agric. 14(3): 28-40.

Odunze, A. C., Tarawali, S. A., de Haan, N. C., Akoueguon, E., Amadji, A. F., Schultze-Kraft, R. and Bawa, G. S. (2004). Forage legumes for soil productivity enhancement and quality fodder production. J. Food Agric. Environ. 2(2): 201-209.

Onyeonagu, C. C. and Eze, S. M. (2013). Proximate compositions of some forage grasses and legumes as influenced by season of harvest. African J. Agric. Res. 8(29): 4033-4037.

Patel, A. S., Sadhu, A. C., Patel, M. R. and Patel, P. C. (2007). Effect of zinc, FYM and fertility levels on yield and quality of forage maize. Forage Res. 32(4): 209212.

Pathan, S. H., Tumbare, A. D. and Kamble, A. B. (2012). Impact of planting material, cutting management and fertilizer levels on nutritional quality of bajra $\times$ napier hybrid. Forage Res. 38 (2): 74-79.

Rostamza, M., Mohammad-Reza, C., Mohammad-Reza, J. 
and Ahmad, A. (2011). Forage quality, water use and nitrogen utilization efficiencies of pearl millet (Pennisetum americanum L.) grown under different soil moisture and nitrogen levels. Agric. Water. Manag. 98: 1607-1614.

Russo, V. M. (2006). Mineral nutrient and Protein contents in tissues, and yield of navy bean, in response to nitrogen fertilization and row spacing. J. Food Agric. and Environ. 4(2): 168-171.

Salis, L. and Vargiu, M. (2008). Influence of mineral fertilization on production and quality of forage in a Sardinian pasture. Grassl. Sci. Eur. 13: 308-310.

Sharma, A. and Chandra, A. (2004). Effect of plant density and nitrogen levels on physiochemical parameters of cauliflower. Haryana J. Hort. Sci. 33: 148-149.

Sharma, A. K., Sharma, A. K., Sharma, R. K., Rajiv, B. and Rai, P. K. (2012). Effect of different levels of nitrogen, organic manure and planting time on yield and quality of hybrid napier. Indian J. Anim. Nutr. 29(1): 33-39.

Thavaprakaash, N., Velayudham, K. and Muthukumar, V. B. (2008). Response of Crop Geometry, Intercropping Systems and INM Practices on yield and fodder Quality of Baby Corn. Asian J. Scientific Res. 1(2): 153-159.

Tilley, J. M. A. and Terry, R. A. (1963). A two stage technique for the in vitro digestion of force crops. British $J$. Grassl. Soc. 18: 104-111.
Tiwana, M. S., Puri, K. P., Tiwana, U. S. and Singh, A. (2004). Forage production potential of napier-bajra hybrid varities under different nitrogen levels. Forage Res. 30: 80-85.

Vasileva, V. and Ilieva, A. (2011). Chemical composition, nitrate reductase activity and plastid pigments content in lucerne under the influence of ammonium and nitrate form mineral nitrogen. Agron. Res. 9 (1-2): 357-364.

Vinay Raj, D. J. and Palled, Y. B. (2014). Responses of hybrid napier genotype to nitrogen levels. Karnataka $J$. Agric. Sci. 27(1): 74-75.

Vough, L. R. and Marten, G. C. (1971). Influence of soil moisture and ambient temperature on yield and quality of alfalfa forage. Agron. J. 63: 40-42.

Vuckovic, S., Simic, A., Djordjevic, N., Zivanovic, T., Stojanovic, I. and Stanisavljevic, R. (2005). Effect of nitrogen fertilizer and underseeding on the productivity and chemical composition of Cynosuretum cristati type meadows on hilly-mountainous grassland in Serbia. Grassl. Sci. Eur. 10: 489-492.

Wang, Z. Q., Yuan, Y. Z., Ou, J. Q., Lin, Q. H. and Zhang, C.F. (2007). Glutamine synthetase and glutamate dehydrogenase contribute differentially to proline accumulation in leaves of wheat (Triticum aestivum) seedlings exposed to different salinity. J. Plant Physiol. 164: 695-701. 